\title{
Force And Threat Of Violence Are As The Ways Of Commission Of Rape: National And Foreign Experience
}

\section{F.Kh.Khudaykulov}

Lecturer,Department of Criminal Law, Criminology and Fight against Corruption, Tashkent State University Law,Tashkent, Uzbekistan, E-mail: dr.profi114@gmail.com

\begin{abstract}
Rape and other sexual assaultsare commonly committed in industrialized countries, and are becoming more common throughout the world. Insome countries' jurisdictions, male-female rape is the only form of rape counted in the statistics. many countries may not define forced and threat of violence sex on a spouse as "rape". But those criminal acts are considered a crimein criminal law which belongs to those countries. Although rape is expressed the same in the legislation of different countries, it differs in some. rape as a crime is three the ways of commission crime. They are force, threat and sexual intercourse committed by abuse of helpless. Sometimes rape is committed by other means, with children, serious bodily injury and others. Some terms are used by legislation of different countries. They are: sexual act, sexual contact, force, threat, abuse of helpless, serious bodily injury from rape, by other means. Rape is committed by force or threat knowingly causes another person to engage in a sexual act by using force against that other person or by threatening or placing that other person in fear that any person will be subjected to death, serious bodily injury, or kidnapping or attempts to do so, shall be fined under this title, imprisoned for any term of years or life, or both. On other hand rape is committed by other means knowingly renders another person unconscious and thereby engages in a sexual act with that other person or administers to another person by force or threat of force, or without the knowledge or permission of that person, a drug, intoxicant, or other similar substance and thereby substantially impairs the ability of that other person to appraise or control conduct and engages in a sexual act with that other person or attempts to do so, shall be fined under this title, imprisoned for any term of years or life, or both. Rape is committed with children means that criminal act knowingly engages in a sexual act with another person who has not attained the age of 12 years, or knowingly engages in a sexual act under the circumstances with another person who has attained the age of 12 years but has not attained the age of 16 years (and is at least 4 years younger than the person so engaging). But in the criminal code of Uzbekistan with children is considered in a sexual act with another person who has not attained the age of 14 years.
\end{abstract}

This article illustrates that the ways commission ofrape, including the theoretical and practical problems of the ways commission of rape. As well as in this article are given relevant conclusions, suggestions and recommendations by the analysis of the criminal law of developed foreign countries (USA, Canada, England and Wales, New Zealand, Germany, France and Russia).

In addition, proposals and recommendations for further improvement of the criminal legislation of the Republic of Uzbekistan.

Keywords:rape,sexual act, sexual contact, sexual assault, force, threat of violence, abuse of helpless, serious bodily injury, by other means

Article Received: 10 August 2020, Revised: 25 October 2020, Accepted: 18 November 2020

\section{Introduction}

The United Nations statistical report compiled from government sources showed that more than 250,000 cases of rape or attempted rape were recorded by police 
annually. The reported data covered 65 countries.

A negative social phenomenon such as crime that hinders the development of society and the progress of reforms. Fighting against it can give the expected effect only if the current laws are strictly followed. One of the tasks of a democratic state based on the rule of law is to ensure that members of society abide by the law, increase the responsibility of law enforcement agencies in this regard, crimes, in particular, the improvement of measures to prevent sexual offenses.

The fight against crime as a rapeand prevention of the crime of rapeare the basis of law enforcement activities.According to statistics, in some countries of the world there is an increase in crimes of this type and in some countries, there is a decrease. For example, in Uzbekistan according to statistics on criminal cases reviewed by criminal courts during 2014-2019which the number of persons convicted of rape (Article 118 of the Criminal Code) totaled 1,633. But the instability of the dynamics of sexual crimes does not affect the level of their social danger and their legal content, because this type of criminal act differs from other crimes in that it has a high level of social danger and infringes on a person's sexual freedom and inviolability. Some types of sexual crimes like as homosexuality and forced sexual intercourse are declining In Uzbekistan, but there is an increase in offences of rape and sexual abuse in an unnatural way. This indicates the imperfection of the norms of criminal law established for liability for these crimes and the low level of legal knowledge of the population.

The significance of this research work is to study the criminal and legal laws of foreign countries on the fight against sexual crimes and based on the study of their experience in this area, comments were made on the identification and elimination of shortcomings in the criminal law. Along with this research work study is not only criminal responsibility for the crimes of sexual norms of the law of foreign countries, but also analyzed their general features of the criminal law system, which further enhances its importance and enriches its content.

Rape is a sharply under-reported crime. This crime with surveys showing dark figures of up to $91.6 \%$ of rapes going unreported. Reasons for not reporting rape differ among the countries. They may include fear of retaliation, not wanting others to know about the rape, not wanting the offender to get in trouble and fear of prosecution (e.g. due to laws against premarital sex). Most rape reporting to date has been limited to male-female forms of rape. However, almost no research has been done on female-female rape, though women can be charged with rape in a few jurisdictions in some countries.

\section{Methodology}

This study is based on a sample of 1,633 cases of solved rapes thatwere committed in Uzbekistan between 2014 and 2020. These data were obtained from the Supreme Court database that includes information on the geographic and crime scene behavior of these events, as well as the individuals involved in these crimes. Information about each rape was collected by investigators and judgesduring the investigation, judgetrials and was subsequently entered into the Supreme Court database by crime analysts who are experts in extrafamilial sexual crimes.As well as analyzing of the criminal law of developed foreign countries like as USA, Canada, England and Wales, New Zealand, Germany, France and Russia.

Additional searches were conducted using new search terms with the same criminal codes and criminal laws (excluding 18 U.S. Code chapter 109A - Sexual abuse, Criminal code of Canada, Sexual Offences Act 2003 of UK, Crimes act of New Zealand) with the same exclusion criteria. The search terms were: "sexual violation" AND "decision making" AND"sex offences"; "sexual assault", "sexual intercourse" AND "victim credibility" AND 
"investigative bias"; "male sexual assault" AND investigators; investigators AND victim AND "sexual assault"; "sexual assault" AND "decision making" and judgetrials; and "judgetrials" AND "sexual assault"

\section{Discussion}

Actually there are many terms are related to the rape (sexual offence). They are such as "sexual assault", "sexual intercourse without consent", "criminal sexual conduct", etc. Therefore, in many countries other terms are used instead of rape. Rape is the crime of sexual intercourse (with actual penetration of woman's vagina with the man's penis) without consent and accomplished through force, threat of violence or intimidation (such as a threat to harm a woman's child, husband or boyfriend) [1].

There is no federal law that related to the rape in the United States. In most states, the term "rape" is not used in state laws. Instead of it, other terms are used such as "sexual assault", "criminal sexual conduct", "sexual abuse", "sexual battery" etc.

(a)RAPE. - Any person subject to this chapter who commits a sexual act upon another person by -

(1) using unlawful force against that other person;

(2) using force causing or likely to cause death or grievous bodily harm to any person;

(3) threatening or placing that other person in fear that any person will be subjected to death, grievous bodily harm, or kidnapping;

(4) first rendering that other person unconscious; or

(5) administering to that other person by force or threat of force, or without the knowledge or consent of that person, a drug, intoxicant, or other similar substance and thereby substantially impairing the ability of that other person to appraise or control conduct; is guilty of rape and shall be punished as a court-martial may direct [2].

According to the State lawssexual assault means that any person who commits a sexual act upon another person bythreatening or placing that other person in fear; or making a fraudulent representation that the sexual act serves a professional purpose; or inducing a belief by any artifice, pretense, or concealment that the person is another person;

According to the US laws proof of threat means that a person made a threat, it need not be proven that the person actually intended to carry out the threat or had the ability to carry out the threat.

By the way the term "grievous bodily harm" means serious bodily injury. It includes fractured or dislocated bones, deep cuts, torn members of the body, serious damage to internal organs, and other severe bodily injuries. It does not include minor injuries such as a black eye or a bloody nose.

The term "force" means the use of a weapon; the use of such physical strength or violence as is sufficient to overcome, restrain, or injure a person; or inflicting physical harm sufficient to coerce or compel submission by the victim.

The term "threatening or placing that other person in fear" means a communication or action that is of sufficient consequence to cause a reasonable fear that non-compliance will result in the victim or another person being subjected to the wrongful action contemplated by the communication or action [3].

According to the Article 131 of theCriminal Code of Russia, rape, that is, a sexual intercourse with the use of violence or of a threat thereof, with respect to the victim or to other persons or with the use of a helpless state of the victim -

shall be punishable with deprivation of freedom for a term of three to six years. A rape: 
a) committed by a group of persons, or by a group of persons in preliminary collusion, or by an organised group;

b) connected with a threat of homicide or with causing a grave injury to the health, and also committed with special cruelty with respect to the victim or to other persons;

c) which has entailed the infection of the victim with a venerial disease -

shall be punishable with deprivation of freedom for a term of four to ten years with restriction of liberty for a term of up to two years or without such.

\section{A rape:}

a) of a minor girl;

b) which has entailed, by negligence, the causing of a grave injury to the health of the

victim, the infection of her with AIDS or other grave consequences -

shall be punishable with deprivation of freedom for a term of eight to fifteen years with or without deprivation of the right to hold certain posts or to be engaged in a certain activity for a period of up to twenty years and with restriction of liberty for a term of up to two years.

\section{A rape:}

a) which has entailed by negligence the death of the victim;

b) of a girl victim who has not reached the age of fourteen years -

shall be punishable with deprivation of freedom for a term of twelve to twenty years with or without deprivation of the right to hold certain posts or to be engaged in a certain activity for a term of up to twenty years and with restriction of liberty for a term of up to two years.

The deed provided for by Item $b$ of Part Four of this Article made by a person with a previous conviction for having committed an offence against sexual integrity of a minor -

shall be punishable by deprivation of liberty for a term of fifteen to twenty years with deprivation of the right to hold definite offices or to engage in definite activities for a term of up to twenty years or by life imprisonment [4].

According to the English law (England and Wales)rape is a statutory offence which is defined as follows: Rape

(1) A person (A) commits an offence if he intentionally penetrates the vagina, anus or mouth of another person (B) with his penis; in this situation $\mathrm{B}$ does not consent to the penetration, and (A) does not reasonably believe that $\mathrm{B}$ consents.

According to the French penalty code any act of sexual penetration, whatever its nature, committed against another person or on the perpetrator, by violence, constraint, threat or surprise, is rape. Rape is punished by a maximum of fifteen years' criminal imprisonment. Rape is punished by a maximum of twenty years' criminal imprisonment in certain aggravating factors (including victim under age of 15). Rape is punished by a maximum of thirty years' criminal imprisonment where it caused the death of the victim. Rape is punished by a maximum of imprisonment for life when it is preceded, accompanied or followed by torture or acts of barbarity [5].

In New Zealand instead of rape the term of sexual violation is used. According to the law Sexual violation is the act of a person who rapes another person. On the other hand person has unlawful sexual connection with another person. One person may be convicted of the sexual violation of another person at a time when they were married to each other [6].

In the theory of criminal law, the structure of a legal (specific) crime is a set of legal features, through which the legislature forms a specific type of crime (murder, theft, rape, etc.).

In accordance with Article 14 of the Criminal Code of the Republic of Uzbekistan, A culpable socially dangerous act (action or inaction) prohibited by this Code on pain of imposing of a penalty shall be recognized as a crime. So, according to 
this definition, any action or inaction shall be recognized as a crime only in the presence of public danger, illegality, guilt, penalty[7].

According to the Article 118 of theCriminal Code of Uzbekistan, Rape, that is, a sexual intercourse committed by force, threats, or abuse of helpless -

shall be punished with imprisonment from three to seven years.

\section{Rape:}

a) of at least two persons;

b) committed repeatedly, by a dangerous recidivist or a person previously committed a crimeenvisaged by Article 119 of this Code; individuals;

c) committed by a group of

d) committed with a threat to kill -

shall be punished with imprisonment from seven to ten years.

\section{Rape:}

a) of a person known to be under eighteen years of age;

b) of a close relative;

c) committed by a member of a mass disorder;

d) committed by a special dangerous recidivist;

e) that resulted in a grave consequences -

shall be punished with imprisonment from ten to fifteen years.

Rape of a person known to be under fourteen years of age -

shall be punished with imprisonment from fifteen to twenty years.

Actually,force and threat of violence are as the ways of commission of the crime in rape.

So force or the threat of its use in the corpus delicti under Art. 118 and 118 of the Criminal Code is a constructive sign of objective side - theway (method) of committing a socially dangerous act. Without delving into the discussion of the concept of the way of committing a crime, we try to give the definition. For example, the ways of committing a crime: "techniques, methods, tactical means used to commit a crime" [8, p. 17].

Most often, the way commission of a criminal offence is as a constructive or qualifying signs of the corpus delicti. The way commission of a criminal offence is considered an obligatory element of the crime in cases when the legislator in the article of the criminal code indicates it.

Thus, the forms of rape (art. 118) and sexual intercourse with person under sixteen years of age (art. 128) differ in the way they are committed, directly indicated in Articles. Rape is committed with a sexual intercourse by force, threats, or abuse of helpless.

As a result of rape, the victim may become pregnant.Usually she tries to abort the fetus.

Currently, the legislation of the Republic of Uzbekistan does not prohibit the abortion (artificial termination of pregnancy), however, such an operation is allowed only in medical institutions and in the absence of medical contraindications [9].

Often, the way of committing a crimeaffects the degree of socially dangerousact (action or inaction). In such cases, thelegislator identifies it as a qualifying sign.For example, rape is is committed with a threat to kill ("d" of part 2 of article 118 of the Criminal Code of the Republic of Uzbekistan.)

The way of committing a crime, even if it is not an obligatory or qualifying sign, it has great importance for the individualization of punishment.

Depending on the way of committing a crime, articles of the Criminal Codes of CIS [10] (The Commonwealth of Independent States) can be classified dispositions are: 
1) the single way to commit a specific crime is mentioned;

2) contains an exhaustive list of ways to commit a crime and;

3) contains an approximate list of ways to commit a crime;

4) The way of committing a crime is not specified and, therefore, can be any.

The objective side of rape consists of two consecutive actions. They are physical violence or the threat of its use by the offender to the injured victim and subsequent sexual intercourse in how it previously determined natural form. Rape using the helpless state is usually committed without prior physical or mental violence against the victim.

As we say at the top, the term "force" means the use of such physical strength or violence as is sufficient to overcome, restrain, or injure a person; or inflicting physical harm. We may also add to one type of the force is the use of a weapon.

In cases where threat is manifested as an element of the objective aspect of another crime, it serves as a way and means to break the victim's resistance, to influence his psyche in order to intimidate him with this or that kind of injury if he does not comply with the guilt.

For example, according to the case identified in court, from September 17, 2019 to December 24, 2019, I. threatened to hand over a $\mathrm{CD}$ with the voice of $\mathrm{D}$., who allegedly had sex with other men, and forced her to have sex with him. I. continued his criminal activities and on November 24, 2019 , at 8:30 p.m., in order to satisfy his sexual needs, he threatened to have sex with her and forcibly rapedD. in Tashkent, Hamza district, house 19, apartment 78, despite her resistance. I. was found guilty of committing part 1 of Article 118 of the Criminal Code of the Republic of Uzbekistan and sentenced to 3 (three) years of imprisonment [11].

There are two main types of threat in criminal law theory. They are: threat by violence and threat by killing. The study of the results of the court practice shows that "threat" in Part 1 of Article 118 of the Criminal Code is committed precisely by threatwith the use of violence. Criminal legislation of foreign countries (USA, Canada, Germany, Estonia, the Russian Federation, Kazakhstan, Kyrgyzstan, Tajikistan) also stipulates exactly the type of threat with the violent.

Another example, B. entered the apartment on June 23, 2020 at $11.30 \mathrm{pm}$ with the purpose of sexual intercourse while consuming alcohol, through the kitchen window of the apartment, in Military town, Hamza district, Tashkent. At that time G. was slept in the hotel. When she was lying on the bed, she was forced to have sex by B. He used force, threats, or abuse of helpless, repeatedly hitting her on the head and various parts of her body. Then he tried to hide from the crime scene. B. was found guilty of committing a rape under Part 1 of Article 118 of the Criminal Code of the Republic of Uzbekistan and sentenced to 4 (four) years of imprisonment under this article. He was sentenced to serve his sentence in a penal colony.

Violence in criminal law is understood to be intentional and unlawful physical force against another person who infringes on it bodily integrity, health or life restricting or excluding his freedom.As well as intentional unlawful influence on the psyche of another person to suppress his or her will, or forced certain actions or omissions, as well as actions, characterized by the real possibility of harm to protected by law in the interests, accompanied by a mental impact on the victim

$$
\text { [12, p. 24-26]. }
$$

Criminal law uses the term "violence" in the sense of physical influence. The threat has a different meaning: either as a mental effect (not called violence), or as a real danger of harm [13, p. 72-75].

For example, according to the case identified in court, Z. committed a rape in 26 July 2020 year. Anattempt to sexual intercourse committed by force and threat by 
Z. to E. E. was born on April 11, 1989, living at " $\mathrm{R}$ " Street, in Bekabad district. In 26 July 2020 year, E. was attempted to sexual intercourse committed by force and threat while she was doing housework in the yard of her house by Z. At that time $\mathrm{Z}$. was drunken when he entered in the house. Taking advantage of the absence of a spouse in her house, Z. at the time when E. was doing household chores in the courtyard of the living room, $\mathrm{Z}$. was in a drunken state, he came into the house, touching her disgrace, that is, using violence, in order to try to have sex with E. When he was going to have sex by pulling her hair and taking her from her house yard into house, giving her a mouth, holding with strength from different parts of her body. Neighbor B. came into the house after hearing her shouting and asking for help. It was found that Z. was attempting to sexual intercourse to E. committed by force and threat. Z. was found guilty under part 1 of Article 25,118 of the Criminal Code of the Republic of Uzbekistan. He was sentenced to 3 (three) years of imprisonment in accordance with Part 1 of Article 25,118 of the Criminal Code of the Republic of Uzbekistan. The sentence was to be served in a penal colony [14].

Under the threat to kill, provided for in paragraph "d" of part two of article 118 of the Criminal code should be understood not only the direct statements of the perpetrator, which is expressed the intention of immediate use of physical violence to the victim. And his close relatives or other persons against whom the victim has a certain responsibility, but also such threatening actions of the perpetrator, such as, for example, demonstration of weapons or objects that can be used as weapons (knife, razor, ax, etc.) [15].

Force and threat of violence are obligatory signs of the objective side of rape and they are as the ways of commission of the crime in rape.

According to statistics and criminological research, rape increases in spring and summer, when hot weather, low amount of clothing, spending more time on the street, in parks, alleys create favorable conditions for the commission of sexual violence.

\section{Results}

After analyzing developed foreign countries' criminal law and penal codes (18 U.S. Code chapter 109A - Sexual abuse, Criminal code of Canada, Sexual Offences Act 2003 of UK, Crimes act of New Zealand, German, Russia Criminal codes and French Penal code), we will be able support their laws. After that, we should give some proposals. They are:

Rape, that is, a sexual intercourse committed by force, threats, violence, constraint, threat, surprise, or abuse of helpless -

\section{shall be punished with imprisonment from three to seven years.}

In fact, force and threat of violence have criminal legal aspects as follows: They are:

First one is they may be mentioned in criminal code by legislative as the obligatory signs of the objective side of the crime at the qualification of the criminal offence. For example, according to the Criminal code of the Republic of Uzbekistan, facultative sign (exactly the way of committing a crime - force, threats) of the objective side of the crime is mentioned as obligatory sign at the article 118 of the Criminal code. According to article 118, rape, that is, a sexual intercourse committed by force, threats, or abuse of helpless. Force, threats is the way of committing a crime.

Second one is they may be mentioned in criminal code by legislative as the qualifying elements at the qualifying offense (criminal act). For example, according to the Criminal code of the Republic of Uzbekistan, facultative sign (exactly the way of committing a crime threats) of the objective side of the crime is mentioned as obligatory sign at the article 118, part 2 paragraph " $d$ " of the Criminal 
code. That is, rape is committed with a

threat to kill.

Table 1: Statistics provided by the Supreme Court of the Republic of Uzbekistan by letter No. 09 / 2649-30 of September 23, 2020 of the criminal cases examined under certain articles in criminal courts for $2015-2020$

\begin{tabular}{|c|c|c|c|c|c|c|c|c|c|c|}
\hline \multirow[t]{2}{*}{ Years } & \multirow{2}{*}{$\begin{array}{l}\text { Num } \\
\text { ber of } \\
\text { perso } \\
\text { ns } \\
\text { found } \\
\text { guilty }\end{array}$} & & & \multicolumn{7}{|c|}{ ARTICLE 118 OF THE CRIMINAL CODE OF UZBEKISTAN } \\
\hline & & & & \multicolumn{7}{|c|}{ MAIN IMPOSED PENALTIES } \\
\hline 1 & 2 & 3 & 4 & 5 & 6 & 7 & 8 & 9 & 10 & 11 \\
\hline & & $\begin{array}{l}\text { Fi } \\
\text { ne }\end{array}$ & $\begin{array}{l}\text { Deprivat } \\
\text { ion of } \\
\text { Certain } \\
\text { Right }\end{array}$ & $\begin{array}{l}\text { Compuls } \\
\text { ory } \\
\text { public } \\
\text { works }\end{array}$ & $\begin{array}{l}\text { Correcti } \\
\text { onal } \\
\text { Labor }\end{array}$ & $\begin{array}{l}\text { Restrict } \\
\text { ion of } \\
\text { freedo } \\
\text { m }\end{array}$ & $\begin{array}{l}\text { Imprison } \\
\text { ment }\end{array}$ & $\begin{array}{l}\text { ja } \\
\text { il }\end{array}$ & $\begin{array}{l}\text { Conditi } \\
\text { onal }\end{array}$ & $\begin{array}{l}\text { senten } \\
\text { ced on } \\
\text { other } \\
\text { groun } \\
\text { ds }\end{array}$ \\
\hline $\begin{array}{l}2015 \\
\text { year }\end{array}$ & 481 & 1 & & & 19 & & 444 & 1 & 15 & 1 \\
\hline $\begin{array}{l}2016 \\
\text { year }\end{array}$ & 412 & 1 & & & 15 & 15 & 358 & & 21 & 2 \\
\hline $\begin{array}{l}2017 \\
\text { year }\end{array}$ & 322 & & & & 4 & 23 & 278 & & 15 & 2 \\
\hline $\begin{array}{l}2018 \\
\text { year }\end{array}$ & 168 & & & & 3 & 15 & 141 & & 8 & 1 \\
\hline $\begin{array}{l}2019 \\
\text { year }\end{array}$ & 154 & & & & 1 & 6 & 139 & & 8 & \\
\hline $\begin{array}{l}2020 \\
\text { year }\end{array}$ & 96 & & & & 1 & 9 & 83 & & 3 & \\
\hline $\begin{array}{l}\text { TOT } \\
\text { AL }\end{array}$ & 1633 & 2 & 0 & 0 & 43 & 68 & 1443 & 1 & 70 & 6 \\
\hline
\end{tabular}

In research study is analyzed statistical data, provided by the Supreme Court of the Republic of Uzbekistan, the letter number 09 / 2879-42 of 23September 2020 examined the criminal cases in the criminal courts for 2015- 2020 years under certain article of the Criminal Code of the Republic of Uzbekistan on crime rape.As a result of which, it is obvious that a large number of rapes are committed against article 118 . "Rape, that is, a sexual intercourse committed by force, threats, or abuse of helpless", where it peaks in 2015 (481) and the lowest in 2020 (96). Imprisonments were imposed as penalty by courts where it peaks in 2015 (444) and the lowest in 2020 (83). Fines were imposed as penalty by courts rarely. Correctional Labors were imposed as penalty by courts where it peaks in 2015 (19) and the lowest in 2020 (1). Restriction of freedoms were imposed as penalty by courts where it peaks in 2017 (23) and the lowest in 2019 (6). Jails were imposed as penalty by courts rarely which in 2015-2020 years (2). 
Preliminary forensic biological examinations of rape in Uzbekistan are conducted not at the Republican Center for Forensic Examination, but at the Republican Center for Forensic Medicine and its regional offices. The scientific literature states that in the unwashed female body, the male sperm can be stored for up to 72 hours. Then it is absorbed into the body. Accordingly, it is desirable to apply for as short periods as possible when sexual assault occurs.

If the examination reveals indeed signs of sexual assault, in addition to the physical evidence, DNA examination is ordered to clarify the identity of the perpetrator only if a male sperm is found in the body of a woman. Through DNA examination, it is determined that the crime of sexual assault was committed by one or more persons. According to the expert's conclusion, it is clarified that this crime was committed by suspected persons or others. Such examinations are appointed only on the basis of documents of the investigative or judicial authorities, such examinations are not conducted on private appeals.

In Tashkent, 15 rapes were committed in the first half of this year. This is 7.5 times more than in the same period last year. In the first half of 2019, there were 2 cases of rape in the capital. Such crimes have not increased only in Tashkent. In Jizzakh region it increased from 3 to 9 and in Tashkent region from 6 to 11. This was stated in the Twenty-First Plenary Session of the upper chamber on defense and security issues of the Senate of the Oliy Majlis (parliament).

In addition, The direct participation of juveniles in rape crimes also increased by $25 \%(48-60 \%)$ in Tashkent region, and crimes committed by groups in Tashkent $(14.7 \%)$, Surkhandarya (1\%) and Fergana $(0.7 \%)$ regions.

Adult crime remains a serious problem for Russia, despite the reduction in their number. This requires the improvement of the measures we have and the search for new measures [16].

\section{Conclusion}

In conclusion, analyzing some of the rules that have long been effectively used in the practice of some foreign countries, we pay attention to the issues of improving the norms of the Criminal Code of the Republic of Uzbekistan on sexual crimes:

First of all, special attention should be paid to the issue of the liberalization of responsibility and punishment for sexual crimes. In particular, in many countries use of corporal punishment as a fine for certain types of sexual crimes is effective.

Secondly, it is expedient to improve the norms of criminal liability for prostitution and to establish criminal liability for prostitution if it is repeated within a year. (for example, there are such articles in the Criminal Codes of Austria, Thailand and others).

Thirdly, in the criminal law of most foreign countries (USA, Canada, England, New Zealand, Germany, France, Belgium and Israel) if sexual crimes are committed against a minor, adopted child, stepchild or daughter, foster child, a person entrusted with control or education,these sexual crimes are reinforced as an aggravating circumstance. In our view, it is worthwhile to make some amendments to our national legislation with taking into account this situation.

Fourth, it would be worthwhile to take into account a situation in the legislation of a number of countries on the liberalization of liability for sexual crimes.In these countries, if the marriage between the victim and the offender is agreed upon and the victim agrees, the offender is released from liability. In this sense, the use of this rule in the liberalization of our criminal law can be effective.

In short, the system of crimes against the person has its own relatively stable dynamics, responsibility and punishment for sexual crimes that grossly violate the established moral and cultural traditions of society, in other words, criminal and criminological measures. It is important to 
study the criminal law of foreign countries and draw the necessary conclusions on the basis of a comparative comparison with our national legislation.

\section{References}

[1] http://legal-

dictionary.thefreedictionary.com/rape

[2] United States Code: Title 10,920. Art. 120. Rape, sexual assault, and other sexual misconduct | LII / Legal Information Institute Law.cornell.edu (2013-03-03). Retrieve on 2013-03-03.

[3] www.law.cornell.edu/uscode/text/10/ 920

[4] Criminal code of Russian Federation // Legal Russia: federal legal portal (v. 3.2). http://law.edu.ru (Уголовный кодекс Российской Федерации // Юридическая Россия: федеральный правовой портал (v. 3.2). http://law.edu.ru)

[5] "en - English / Traductions / Accueil | Legifrance - Le service public de l'accès au droit"(in French). 195.83.177.9. Retrieved30 December 2012 .

[6] http://www.legislation.govt.nz/act/pu blic/1961/0043/latest/whole.html

[7] X.Ochilov, D.Kamalova. Criminal responsibility for inchoate offence according criminal code of the republic of Uzbekistan // International Journal of Advanced Science and Technology Vol. 29, No. 5, (2020). - P. 1730.

[8] Galakhova A. V. Issues of qualification of crimes in criminal law and judicialpractice (based on the objective side) // Russian Investigator. 2010. No. 14. - P. 17.

[9] Nozimakhon Gafurova, Bakhtiyar Khidoyatov, Vokhid Sunnatov. Criminal responsibility of medical workers: national and foreign experience // International Journal of Pharmaceutical Research |Apr Jun 2020 | Vol 12 | Issue 2. - P. 157.

[10] The Criminal Code of the Republic of Estonia(with amendments and additions as of 06/11/2018).www. estonia.news- city.info // The Criminal Codeof the Republic of Belarus (withamendments andadditions as of 2020). www. kodeksy.by //Criminal Code of the Republic of Kazakhstan (withamendments and additions as of 2020).www. zakon.uchet.kz // Criminal Code of theRepublic of Kyrgyzstan (with amendments andadditions as of January 2020). www. online.zakon.kz. [11] From the archives of the Hamza district court on criminal cases. - Criminal case number 1-378/13.

[12] Bezruchko E. V. the Use of the term "violence" in criminal the legislation of Russia // Criminal law. 2014. № 5. - P. 2426.(Безручко Е.В. Использование термина "насилие" в уголовном законодательстве России // Уголовное право. 2014. № 5.)

[13] Kruglikov L.L. On the concept and the criminal legal assessment of violence // Criminal law. 2015. № 1. - P. 7275.(Кругликов Л.Л.О понятии и уголовно-правовой оценке насилия // Уголовное право. 2015. № 1.)

[14] From the archives of the Bekabad district court on criminal cases. - Criminal case number 1-2204-2001/32 // https://public.sud.uz/\#!/sign/criminal.

[15] Resolution of the Plenum of the Supreme Court of the Republic of Uzbekistan. October 29, 2010 № 13 “On judicial practice on cases of abusive and abusive treatment of sexual orientation" // https://lex.uz/docs/2414120 // National database of legislative data // 2010 year 29 October, Number 13. (Ўзбекистон Республикаси Олий суди Пленумининг 2010 йил 29 октябрдаги 13-сонли "Номусга тегиш ва жинсий эхтиёжни ғайритабиий усулда қондиришга доир ишлар бўйича суд амалиёти тўғрисида"ги қарори).

[16] Kumriniso R. Abdurasulova, Begzod A. Umirzakov // International Journal of Psychosocial Rehabilitation, Volume 24, Special Issue 1, 2020. - P. 830. 